\title{
Money to flow again at NIH, but how long will it last?
}

\section{Washington}

THE National Institutes of Health (NIH) last week made a decision that will be music to their grant-holders' ears: money withheld from new grants awarded since the beginning of the year will be given back. But the respite may be brief. The plan to carry $\$ 334$ million forward from the 1987 to the 1988 NIH budget, which initially prompted NIH's frugal action, is still on offer. Even if the money stays put, funds will be short in 1987 and could be extremely short in 1988 .

The money to be handed back was part of the $\$ 334$ million shift - known as extended availability - that would have lowered the 1987 budget to $\$ 5,850$ million, even though Congress had already made its appropriation for 1987 at $\$ 6,184$ million. For 1988, the Reagan administration requested $\$ 5,535$ million, but with the money held over from 1987 the actual amount available for grants would be very close to the previous year's levels.

Congress must pass legislation in order to comply with the extended-availability scheme. So far that does not seem very likely. Senator Edward Kennedy has described the scheme as "robbing Peter to pay Paul". NIH director James Wyngaarden says the institutes have been withholding funds from all research grants since 1 January in order to spread the cuts over the months before 30 September, the end of the fiscal year. Individual institutes were responsible for decisions on how budgets were to be pared, but generally reductions were made across the board.

Some regarded the NIH decision to hold back funds as illegal. Approximately two dozen organizations, including the the Association of American Universities, were considering filing a lawsuit forcing $\mathrm{NIH}$ to release the funds. But legal action now seems unnecessary. On 24 February, $\mathrm{NIH}$ received instructions from the White House Office of Management and Budget (OMB) to release the money. The OMB made it clear that NIH should not "defer or otherwise restrict" currently available money until Congress gave its approval. But OMB spokesman Ed Dale says holding back funds did at first fit in with OMB's plans, although the cuts were not to be across the board.

It is still possible that Congress will agree to take the $\$ 334$ million out of the 1987 budget. This could result in budgetary upheaval if all the savings had to come from money to be awarded in the final quarter of the year. But if the money is not shifted, the net result will be a 10 per cent drop in the NIH budget for 1988 .

Joseph Palca

\section{Award for high-flyers at annual SDI black-tie banquet}

\section{Washington}

BUILding a strategic defence requires more than hardware, it needs dedicated people as well. That was the message from Lt-General James Abrahamson, director of the Strategic Defense Initiative (SDI) Office, as he helped last week to celebrate the second annual Strategic Defense Initiative Technical Achievements Awards Banquet sponsored by the American Defense Preparedness Association (ADPA).

An appreciative crowd packed the main ballroom at the Washington Hilton to see this year's winners receive their laurels. Seated among the military brass and defence contractors was last year's winner of the ADPA Strategic Defense Award, James Fletcher, administrator of the National Aeronautics and Space Administration. This year's award went to Edward Teller, associate director emeritus of Lawrence Livermore Laboratories, and Major-General Robert Rankine, director of space systems command, control and communications for the Air Force.

The evening was full of patriotic sentiment. The presentation of the colours was followed by the national anthem, and an invocation suggesting biblical precedents for a strong strategic defence. Dinner was steak and potatoes (filet mignon and Berny potato sticks); decaffeinated coffee was available for the fainthearted.

The awards for technical achievement went to the Delta 180 project, a successful attempt to intercept an orbiting, thrusting target by a thrusting interceptor from a starting separation of 200 kilometres. Runner-up awards went to a test last summer of a low-altitude rocket interceptor, and to Martin Marietta's rapid retargeting and precision pointing (R2P2) facility in Colorado.

Abrahamson was reportedly upset at the name "R2P2" because of its similarity to the robot character in the movie "Star Wars", but he managed a smile when the award was announced.

The laboratory award went to a team at the Air Force Geophysics Laboratory that developed a new long-wave infrared radar. Runners-up were an experiment to generate a multi-gigawatt burst of microwave radiation, and miniature valves to be

\section{Brenner homes in on the human genome}

$D_{R}$ Sydney Brenner, alternatively molecular biology's favourite son and enfant terrible, is to stake a personal claim in the sequencing of the human genome by recruiting a team of "six to twelve" people to carry out a mapping project.

Until recently director of the Laboratory of Molecular Biology of the Medical Research Council (MRC), and now director of the MRC's Molecular Genetics Unit at Cambridge, Brenner plans partly to finance the project with the $\mathbf{1 3 0 0 , 0 0 0}$ of research money that formed a part of his recently awarded Louis Jeantet Foundation Prize. Further funds, between $£ 200,000$ and $£ 250,000$ a year, are being provided by MRC's Cell Board as well as by other undisclosed sources.

The research unit will be based at the Babraham (near Cambridge) site of the Agricultural and Food Research Council's Institute of Animal Physiology (now rechristened the Institute of Animal Physiology and Genetics Research).

Brenner's objective is far from explicit, but appears to involve both the characterization of cells from different tissue types by the genes which are active in them and the use of techniques for copying messengerRNA molecules into DNA so as to identify whole classes of cognate genes, which can then be placed on the human genome by molecular hybridization.

Brenner, who is a member of the US National Academy of Sciences committee on human genome sequencing, is robustly of the view that a successful project need not be as expensive as some of the first estimates of cost, exceeding $\mathbf{\$ 5 0 0}$ million (over 10 years). On the other hand, he says that novel developments in data handling and sorting may be necessary, which is why he is taking an interest in parallelarray processors.

John Maddox

used in kinetic-energy weapons.

Although the evening's emphasis was on scientific achievements spurred by SDI, Teller admitted that SDI work dealt with only "a few essentially new proposals". But Teller believes advances in technology for unmanned spacecraft necessitated by SDI will benefit the scientific community. He speculated on the day when SDI sensors could be trained on interesting astronomical events, such as the supernova in the Large Magellanic Cloud (see Nature 326, 11; 1987 and see page 121 in this week's issue).

This was not a night for criticism of SDI, unless it was for Congress's failure to pursue the programme with enough vigour. Representative Jack Kemp (Republican, New York) got a standing ovation for his keynote speech urging deployment of SDI by 1993 . 